\title{
BR96 sFv-PE40
}

National Cancer Institute

\section{Source}

National Cancer Institute. BR96 SFv-PE40. NCI Thesaurus. Code C1549.

A single-chain immunotoxin consisting of Fv fragments of the BR96 monoclonal antibody (MoAb) and a truncated Pseudomonas exotoxin (PE40) that lacking the binding domain. MoAb BR96 specifically binds to Lewis Y-related carbohydrate antigen, a cell surface antigen overexpressed in many carcinomas. After internalization, PE40 causes ADPribosylation of transcription elong ation factor 2, thereby inactivating elongation factor 2 and inhibiting protein synthesis in the cancer cells. 